\title{
André Malraux, Carnet du Front populaire, 1935-1936
}

\section{Emanuele Kanceff}

\section{(2) OpenEdition}

\section{Journals}

\section{Edizione digitale}

URL: http://journals.openedition.org/studifrancesi/9663

DOI: $10.4000 /$ studifrancesi.9663

ISSN: 2421-5856

\section{Editore}

Rosenberg \& Sellier

\section{Edizione cartacea}

Data di pubblicazione: 1 décembre 2007

Paginazione: 695-696

ISSN: 0039-2944

\section{Notizia bibliografica digitale}

Emanuele Kanceff, «André Malraux, Carnet du Front populaire, 1935-1936», Studi Francesi [Online], 153

(LI | III) | 2007, online dal 30 novembre 2015, consultato il 11 janvier 2021. URL: http://

journals.openedition.org/studifrancesi/9663 ; DOI: https://doi.org/10.4000/studifrancesi.9663

Questo documento è stato generato automaticamente il 11 janvier 2021.

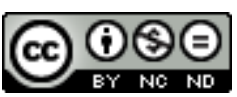

Studi Francesi è distribuita con Licenza Creative Commons Attribuzione - Non commerciale - Non opere derivate 4.0 Internazionale. 


\title{
André Malraux, Carnet du Front populaire, 1935-1936
}

\author{
Emanuele Kanceff
}

\section{NOTIZIA}

ANDRÉ MALRAUX, Carnet du Front populaire, 1935-1936, Préface de Jean-Yves TADIÉ, Édition établie et annotée par François DE SAINT-CHERON, Paris, Gallimard, 2006, pp. 114.

1 «Ce journal n'a aucun caractère personnel. Ce sont seulement des notes d'instants significatifs pour être employées plus tard», così Malraux definiva questi suoi appunti che diario non sono e non vogliono essere. Lontani dal diario intimo, essi sembrano piuttosto rientrare nei canoni del diario o taccuino di viaggio, così come ho avuto occasione di definirlo in un capitolo del mio Poliopticon italiano: notazioni per nulla votate all'introspezione, abbozzi di immagini - come il grido dell'ambulante che vanta la sua merce e che giunge nel silenzio di una situazione tragica, in apertura del quaderno - di fatti, di personaggi, di spettacoli, di paesaggi, legati tutti al tempo, capitale nella storia della Francia, dell'avvento del Front populaire nel 1936. Tutta la politica, le battaglie, le lotte e l'impegno di quegli anni di fuoco sfilano in questo carnet in brevi annotazioni, istantanee di ciò che è fuggevole e insostituibile, cui si affiancano ritagli incollati di giornale, in una girandola di fatti e personaggi, tra i quali i letterati non mancano, così come abbondano confidenze di prima mano sui molteplici aspetti della vita quotidiana e degli incontri anche casuali, e abbozzi di idee, di pensieri, di parole e di espressioni, buttati sulla carta in attesa di approfondimenti. E, non di rado, spuntano delle massime destinate a diventare idee guida dei suoi romanzi, o delle scene e situazioni che la scrittura romanzesca consacrerà per i lettori futuri.

2 Il diario che qui viene pubblicato è un quadernetto di una cinquantina di pagine, di formato che si potrebbe definire tascabile, che risale verosimilmente al periodo compreso tra la primavera del 1935 e la fine di luglio del 1936: periodo che coincide, come è noto, in Francia alle migliaia di scioperi e occupazioni che preludono alla 
vittoria del Fronte popolare, in Spagna allo scoppio della guerra civile, in Europa alla crescita del nazismo. Il testo è completato, in una importante appendice, da brani tratti da un altro piccolo carnet senza date - ma verosimilmente della stessa epoca - che Malraux ha intitolato sulla copertina: Notes / Journal et idées. Vi si può leggere anche la riscrittura che il romanziere ha fatto di passi molto posteriori di diario, a proposito del Front populaire, il testo della sua commemorazione di Leo Lagrange, ucciso in battaglia nel 1940, e di una lettera inedita inviata alla vedova. 